\title{
Eosinophil Protein X Concentration Is Dependent on Eosinophil Concentration
}

\author{
Claudia J. Pronk-Admiraal and Piet C. M. Bartels
}

Department of Clinical Chemistry, Haematology and Immunology, Medical Centre Alkmaar, Alkmaar, The Netherlands

Summary: The relationship between the eosinophil concentration and the serum eosinophil protein $\mathrm{X}$ concentration was investigated in 80 subjects. Higher eosinophil counts resulted in obviously increased serum eosinophil protein $\mathrm{X}$ concentrations. However, the amount of eosinophil protein $\mathrm{X}$ released per eosinophil granulocyte is significantly higher in subjects with lower eosinophil counts.

Atopic subjects $(\mathrm{N}=19)$ show a significantly higher eosinophil concentration $(\mathrm{p}=0.002)$ and eosinophil protein $X$ concentration $(p=0.004)$ and a significantly lower eosinophil protein $X /$ eosinophil ratio $(p=0.02)$, compared with non-atopic subjects $(\mathrm{N}=61)$. However, there appears to be no difference between the concentration of eosinophil protein $\mathrm{X}$ in atopic and non-atopic subjects if the eosinophil concentration is taken into account. When using eosinophil protein $\mathrm{X}$ as an indicator of eosinophil activation, for instance in asthmatic subjects, the eosinophil count should also be considered for correct clinical interpretation of results.

\section{Introduction}

Eosinophils play an important role in the immune response to parasites and in the pathogenesis of certain inflammatory diseases, especially asthma. The granules of the eosinophil granulocytes contain a number of highly cationic proteins, which are released following activation and stimulation of the eosinophil. Release of granule proteins from eosinophils is a selective phenomenon with respect to the individual proteins (1). Several proteins have been characterized, including eosinophil cationic protein and eosinophil protein $\mathrm{X}$, which is synonymous with eosinophil-derived neurotoxin (2). Eosinophil cationic protein and eosinophil protein $\mathrm{X}$ are single chain proteins with relative molecular mass in the range of $M_{\mathrm{r}} 18000-M_{\mathrm{r}} 21000$ and $\mathrm{pI}>11$ and $\mathrm{pI}>9$, respectively (2). The measurement of eosinophil-derived proteins such as eosinophil protein $\mathrm{X}$ in biological fluids may be a useful indicator of eosinophil activation.

Eosinophil protein $\mathrm{X}$ has a lower $\mathrm{pI}$ than eosinophil cationic protein, so that eosinophil protein $\mathrm{X}$ adheres less than eosinophil cationic protein to cell-membranes after degranulation. Eosinophil protein $\mathrm{X}$ might therefore be a more suitable marker for measuring the state of activation of the eosinophil.

Reported ranges of eosinophil protein X concentrations in serum have varied widely over the years and they show large deviations between laboratories $(3,4)$. In the measurement of eosinophil-derived proteins in serum it is particularly important to standardize the handling of the blood samples $(7-10)$. Previous studies have shown that serum concentrations of eosinophil granule proteins are related to the severity of asthma $(5,6)$ and may provide an additional tool for monitoring the efficacy of anti-inflammatory therapy.

In this study the relationship between eosinophil concentration and the serum eosinophil protein $\mathrm{X}$ concentration under standardized conditions is established. Furthermore, atopic and non-atopic subjects within this group are compared, in order to establish differences in eosinophil concentration, eosinophil protein $\mathrm{X}$ concentration and eosinophil protein $\mathrm{X}$ concentration recorded per eosinophil.

\section{Materials and Methods}

Blood samples were taken from 80 apparently healthy adults (males and females, aged 18-60 year). From each subject two serum samples (Vacutainer, ref. 367783, with addition of SST gel and clot activator, Becton Dickinson, Plymouth, UK) and one plasma sample (Vacutainer, ref. 367652, with addition of $\mathrm{K}_{3}$ EDTA as an anti-coagulant, Becton Dickinson, Plymouth, UK) were obtained. After venepuncture, blood samples were clotted for $60 \pm 10$ minutes in a waterbath of $37^{\circ} \mathrm{C}$. After clotting, blood samples were centrifuged at room temperature for 10 minutes at $1350 \mathrm{~g}$. Subsequently the serum samples were stored at $-20^{\circ} \mathrm{C}$ until the serum eosinophil protein $\mathrm{X}$ concentration was measured. Serum eosinophil protein $\mathrm{X}$ concentrations were established with a radioimmunoassay kit (Kabi Pharmacia, Uppsala, Sweden), with an inter-assay coefficient of variation of $4.8-10.6 \%$ as specified by the manufacturer. This range was confirmed by our own experiments. For the eosinophil protein $\mathrm{X}$ concentration a detection limit of $3 \mu \mathrm{g} / \mathrm{l}$ was established. Eo- 
sinophil concentrations in blood samples were determined with a Sysmex NE-8000 haematology analyser (Charles Goffin Medical Systems BV, Tiel, The Netherlands).

IgE concentrations and determination of IgE antibodies specific to inhalant allergens were measured with a radioimmunoassay kit (Total IgE \& Phadiatop; Kabi Pharmacia, Uppsala, Sweden).

\section{Statistics}

The statistical significance of the regression coefficient showing the correlation between eosinophil count and eosinophil protein $\mathrm{X}$ concentration was established by multiple regression analysis. In order to test the statistical significance of differences between the subject groups on the basis of eosinophil concentrations, the MannWhitney-U test was applied. This test was also used to determine statistical differences between atopic and non-atopic individuals.

\section{Results}

Eosinophil protein $\mathrm{X}$ concentrations determined for different eosinophil counts are depicted in figure 1. It is apparent from figure 1 that the eosinophil protein $\mathrm{X}$ concentration increased significantly with higher eosinophil counts. Subsequently, the mean quantity of eosinophil protein $\mathrm{X}$ released per eosinophil was calculated. The whole group $(\mathrm{N}=80)$ was divided into four groups with eosinophil concentrations of $0-0.10 \times 10^{9} / 1(\mathrm{~N}=29)$, $0.11-0.20 \times 10^{9} / 1 \quad(\mathrm{~N}=23), 0.21-0.30 \times 10^{9} / 1$ $(\mathrm{N}=17)$ and $0.31-0.80 \times 10^{9} / 1(\mathrm{~N}=11)$. For each group the median of the eosinophil protein $\mathrm{X} /$ eosinophil ratio was calculated. Results are depicted in figure 2 . A statistically significant increase was found in the eosinophil protein $\mathrm{X} /$ eosinophil ratio in subjects with lower eosinophil counts.

Total IgE concentrations and concentrations of IgE specific to inhalant allergens were determined in the serum samples from 80 apparently healthy subjects. A subject is considered to be atopic when the IgE concentration is above $120 \mathrm{kIU} / \mathrm{l}(11,12)$ and the result for IgE specific for inhalant allergens is positive. Within the 80 subjects,

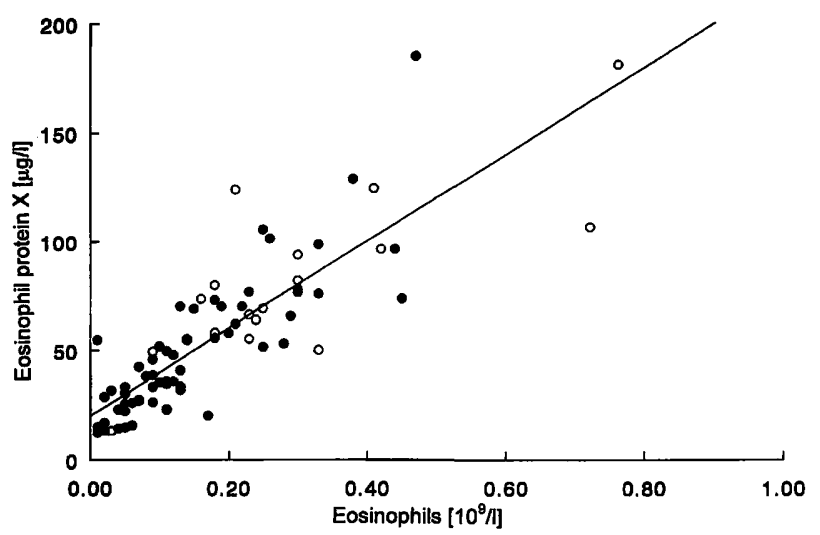

Fig. 1 Eosinophil protein $\mathrm{X}$ concentrations determined in samples clotted at $37^{\circ} \mathrm{C}$ versus eosinophil granulocyte counts in 80 subjects. Black circles represent values for samples of the nonatopic individuals. Open circles show results from samples of the atopic subjects.

Results of statistical analysis:

$y=200 x+20, r=0.84\left(37^{\circ} \mathrm{C}\right), p<0.001$
Tab. 1 Median values of the established analytes in atopic and non-atopic subjects.

\begin{tabular}{lllc}
\hline & p-value & $\begin{array}{c}\text { Median } \\
\text { (atopic) }\end{array}$ & $\begin{array}{c}\text { Median } \\
\text { (non- } \\
\text { atopic) }\end{array}$ \\
\hline $\begin{array}{l}\text { Eosinophil count } \\
\quad\left(10^{9} / 1\right)\end{array}$ & 0.002 & 0.23 & 0.11 \\
$\begin{array}{l}\text { Eosinophil protein } \mathrm{X} \\
\quad(\mu \mathrm{g} / \mathrm{l})\end{array}$ & 0.004 & 69 & 41 \\
$\begin{array}{l}\text { Eosinophil protein } \\
\mathrm{X} / \text { eosinophil }\left(\mu \mathrm{g} / 10^{9}\right)\end{array}$ & 0.02 & 165 & 214 \\
\hline
\end{tabular}

Results of application of the Mann-Whitney U-Wilcoxon rank sum test, in order to establish statistically significant differences between the groups of atopic $(N=19)$ and non-atopic $(N=61)$ subjects. A statistically significant difference is considered to be present when the $p$-value is $<0.05$.

who were all without allergic complaints, $10(25 \%)$ were classified as atopic by application of the criteria mentioned above. The eosinophil concentration, eosinophil protein $\mathrm{X}$ concentration and eosinophil protein $\mathrm{X} / \mathrm{eosi}$ nophil ratio of both groups are reported in table 1 .

The eosinophil concentrations are significantly higher in the atopic subjects (median $\left.=0.23 \times 10^{9} / 1\right)$ than in the non-atopic subjects (median $=0.11 \times 10^{9} / 1, \mathrm{p}=0.002$ ). Eosinophil protein $\mathrm{X}$ concentrations are significantly higher in the atopic group (median $=69 \mu \mathrm{g} / \mathrm{l}$ ) in comparison with the non-atopic group (median $=41 \mu \mathrm{g} / \mathrm{l}$, $p=0.004)$. The eosinophil protein $X /$ eosinophil ratios are significantly lower in the atopic group (median $=165 \mu \mathrm{g} / 10^{9}$ ) than in the non-atopic group (median $=214 \mu \mathrm{g} / 10^{9}, \mathrm{p}=0.02$ ).

\section{Discussion}

The eosinophil protein $\mathrm{X}$ content of eosinophil granulocytes is estimated to be about $17 \mu \mathrm{g} / 10^{6}$ eosinophils

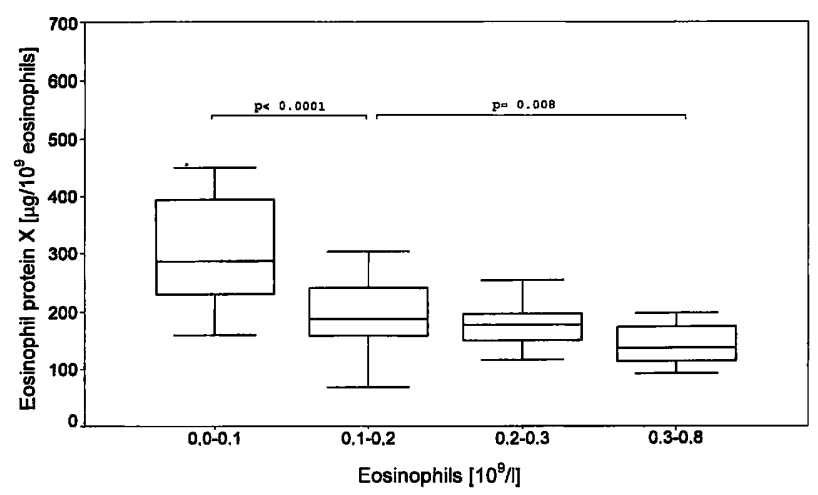

Fig. 2 Median values (horizontal line inside the box) for the eosinophil protein $\mathrm{X} /$ eosinophil ratio in 4 groups representing different ranges for eosinophil concentrations. Boxes indicate the $25^{\text {th }}$ and $75^{\text {th }}$ percentiles. The length of the tail, which is a measure of the scattering of results, is shown by the upper and lower lines. 
(13). When considering this estimate and the results of our study, it should be emphasized that the release of eosinophil protein $\mathrm{X}$ in serum during clotting at $37^{\circ} \mathrm{C}$ amounts to 0.3 to $2 \%$ of the total eosinophil protein $\mathrm{X}$ content of eosinophils. As a consequence, the amount of eosinophil protein $\mathrm{X}$ actually released in vitro is only a small fraction of the total eosinophil protein $\mathrm{X}$ content of eosinophils. A minimal fraction of the eosinophil protein $\mathrm{X}$ concentration in serum might be due to release from neutrophil granulocytes. Compared with eosinophils, neutrophil granulocytes contain only a very small quantity of eosinophil protein $X$, i.e. $1-2 \%$ of the content of an eosinophil granulocyte (14).

Compared with eosinophil protein $\mathrm{X}$, less eosinophil cationic protein is released from eosinophils in vitro ( 9 , 10). The various mechanisms by which eosinophils may be activated and release their granule proteins are only poorly understood. The reason for the differences between eosinophil cationic protein and eosinophil protein $\mathrm{X}$ release is not yet elucidated. One possible explanation may be the fact that eosinophil cationic protein tends to stick more tightly to cell membranes than eosinophil protein $\mathrm{X}$ because of the more basic character of eosinophil cationic protein. In addition, the release mechanisms of these two granule proteins may be different (1). Differences in the mechanisms and kinetics of the clearance of these proteins from the circulation should also be taken into consideration.

It has been demonstrated that eosinophil cationic protein has the ability to bind to clotting factors (15). Particular information concerning the interaction between clotting and eosinophil protein $\mathrm{X}$ release after blood sampling is not yet available. Because of the striking effect of the temperature of serum preparation on in vitro release of granule proteins $(7-10)$, blood samples should be clotted in our opinion at a precisely fixed temperature. We prefer to clot blood samples at $37^{\circ} \mathrm{C}$. This temperature results in a rather extended range of eosinophil protein

\section{References}

1. Capron M, Leprevost C, Prin L, Tomassini M, Torpier G, MacDonald S, Capron A. Immunoglobulin-mediated activation of eosinophils. In: Morley J, Colditz I, editors. Eosinophils in asthma. London: Academic Press, 1989:49-60.

2. Venge $P$, Häkansson L. Current understanding of the role of the eosinophil granulocyte in asthma. Clin Exp Allergy 1991; 21:31-7.

3. Durham SR, Loegering DA, Dunnette S, Gleich GJ, Kay AB. Blood eosinophils and eosinophil-derived proteins in allergic asthma. J Allergy Clin Immunol 1989; 84:931-6.

4. Venge P, Dahl R, Fredens K, Hällgren R, Peterson C. Eosinophil cationic proteins (ECP and EPX) in health and disease. In: Yoshida, Torisu M, editors. Immunobiology of the eosinophil. New York: Elsevier, 1983:163-71.

5. Ahlstedt S, Enander I, Peterson C, Rak S, Venge P. Clinical assessment of the inflammatory component of asthma with emphasis on the eosinophils. Pharma Med 1992; 6:99-111.
$X$ concentrations in samples from different subjects, which are still within the detection range of the kit.

In a previous study it was stated that eosinophils of allergic patients excrete eosinophil protein $\mathrm{X}$ more readily than eosinophils of healthy persons (13). In view of this statement, it may be of clinical importance to calculate the ratio of serum eosinophil protein $\mathrm{X}$ concentration and the eosinophil concentration. When calculating this ratio for apparently healthy subjects, we observed that the amount of eosinophil protein $\mathrm{X}$ released per eosinophil showed a significant tendency to increase with decreasing eosinophil counts. An explanation for this observation might be that eosinophils in samples with a rather high concentration are less primed than eosinophils in samples with lower concentrations of granulocytes. The tendency towards higher eosinophil protein X/eosinophil ratios in the lower eosinophil count ranges might be due inter alia to a bias caused by the relatively high amount of eosinophil protein $\mathrm{X}$ which has already been secreted 'in vivo' at $37^{\circ} \mathrm{C}$. Concerning the laboratory procedure for measurement, the relatively high eosinophil protein $\mathrm{X} /$ eosinophil ratio in the lower eosinophil concentration range might be caused by inaccuracy of the eosinophil count. However, experiments on the effects of diluting the blood samples gave no indication of a systemic deviation in the low eosinophil count range.

With respect to the eosinophil concentration, it is concluded that atopic individuals possess significantly higher eosinophil concentrations than do non-atopic individuals. The eosinophil protein $\mathrm{X}$ concentration is also significantly higher in the atopic group. Finally, the eosinophil protein $\mathrm{X} /$ eosinophil ratio is significantly lower in the atopic group than in the non-atopic group.

\section{Acknowledgements}

We thank Prof. Dr. A. Sturk for critical reading of the manuscript.
6. Zimmerman B, Lanner A, Enander I, Zimmerman RS, Peterson CGB, Ahlstedt $\mathrm{S}$. Total blood eosinophils, serum eosinophil cationic protein and eosinophil protein $\mathrm{X}$ in childhood asthma: relation to disease status and therapy. Clin Exp Allergy 1993; 23:564-70.

7. Kurihara K, Yamada T, Saito H, Iikura Y, Kawaguchi H. Basic research into the measurement of eosinophil cationic protein (ECP) in blood samples. Arerugi 1992; 41:512-8.

8. Pronk-Admiraal CJ, Bartels PCM. Effect of clotting temperature and eosinophil concentration on the eosinophil cationic protein concentration in serum. Scand $\mathbf{J}$ Clin Lab Invest $1994 ; 54: 185-8$.

9. Reimert CM, Poulsen LK, Bindslev-Jensen C, Kharazmi A, Bendtzen K. Measurement of eosinophil cationic protein (ECP) and eosinophil protein X/eosinophil derived neurotoxin (EPX/EDN). J Immunol Methods 1993; 166:183-90. 
10. Venge $P$. Serum measurements of eosinophil cationic protein (ECP) in bronchial asthma. Clin Exp Allergy 1993; 23:3-7.

11. Johansson SGO. Serum IgE levels in healthy adults and children. Int Arch Allergy 1968; 34:1-7.

12. Grigorias C, Pappas D, Galatas ID, Kollias G, Papadimos S, Papadakis P. Serum total IgE levels in a representative sample of a Greek population. Allergy 1993; 48:142-6.

13. Carlson M, Hakansson L, Peterson C, Stalenheim G, Venge P. Secretion of granule proteins from eosinophils and neutrophils is increased in asthma. J Allergy Clin Immunol 1991; 87:27-33.

14. Venge $P$. Soluble markers of allergic inflammation. Allergy 1994; 49:1-8.
15. Venge $P$, Dahl R, Hällgren $R$. Enhancement of factor XII dependent reactions by eosinophil cationic protein. Tromb Res $1979 ; 14: 641-9$.

Received October 7, 1996/February 4, 1997

Corresponding author: Dr. Piet C. M. Bartels, Department of Clinical Chemistry, Haematology and Immunology, Medical Centre Alkmaar, Wilhelminalaan 12, NL-1815 JD Alkmaar, The Netherlands 